\section{Objetivo e Política Editorial}

A Revista Brasileira de Medicina de Família e Comunidade (RBMFC) é uma publicação científica trimestral da Sociedade Brasileira de Medicina de Família e Comunidade (SBMFC), que tem como Missão: sensibilizar estudantes, profissionais e gestores da área da saúde sobre os temas científicos de interesse da Medicina de Famíla e Comunidade (MFC) e da Atenção Primária à Saúde (APS); possibilitar o intercâmbio entre instituições de ensino, serviços de saúde e movimentos sociais organizados; promover a divulgação da abordagem multi e interdisciplinar; servir como veículo de educação continuada e permanente em saúde, tendo como eixos temáticos a MFC e a APS.

ARBMFC tem como objetivo publicar artigos originais, perspectivas, debates e discussões sobre todos os aspectos da MFC e da APS, incluindo a prática clínica, a formação profissional, a organização dos serviços e as políticas públicas relacionadas à MFC e à APS.

\section{Processo de avaliação pelos pares}

Os artigos submetidos à RBMFC serão avaliados por membros de seus Conselhos Editorial e Científico, como também por pareceristas convidados ad hoc. O processo de avaliação por pares preservará a identidade dos autores e suas afiliações. Os artigos serão encaminhados inicialmente ao editor para triagem e avaliação preliminar e, posteriormente, distribuídos aos pareceristas, em conformidade com as áreas de atuação e especialização dos mesmos, bem como com o tema tratado no artigo.

Todos os textos são submetidos à avaliação de dois consultores pareceristas - provenientes de instituição diferente daquela do(s) autor(es) -, em um processo cego, no qual os trabalhos são analisados em relação aos seguintes aspectos: adequação do título ao conteúdo; estrutura da publicação; clareza e pertinência dos objetivos; metodologia; resultados e discussão; informações inteligíveis; citações e referências adequadas às normas técnicas adotadas pela revista e pertinência à linha editorial da publicação. Os consultores preenchem o formulário de parecer, aceitando, recusando ou recomendando correções e/ou adequações necessárias. Todo parecer incluirá sua fundamentação. Esse processo de avaliação inicial dura, em média, dois meses.

No caso de solicitação de alterações no artigo, este poderá ser reencaminhado em até 60 dias, para nova avaliação dos consultores. O resultado final, então, é comunicado ao(s) autor(es). Se aprovado, o artigo é revisado ortográfica e gramaticalmente. As alterações eventualmente realizadas são encaminhadas para aprovação formal dos autores, antes de serem encaminhados para publicação. Será realizada revisão ortográfica e gramatical dos resumos e títulos em língua inglesa e espanhola, por revisor especializado. Não serão admitidos acréscimos ou modificações após a aprovação da revisão final. Os artigos ficam, então, disponíveis para publicação em ordem de protocolo.

A partir de 2011, a RBMFC adotou a publicação de artigos Ahead of Print, ou seja, os textos completos dos artigos são publicados individualmente na edição eletrônica, intitulada como Artigos Aprovados, assim que são finalizados os seus procedimentos editoriais. Esses artigos serão publicados nas próximas edições impressas da RBMFC.
Os artigos devem destinar-se exclusivamente à RBMFC, não sendo permitida sua apresentação simultânea a outro periódico. As contribuições podem ser apresentadas em português, inglês ou espanhol. Temas relevantes em MFC e APS, assim como anais de congressos da área, a critério do Editor, podem ser publicados como suplementos especiais.

Os artigos submetidos devem atender à Política Editorial da RBMFC e às Diretrizes abaixo, que seguem os Requisitos Uniformes para Manuscritos apresentados a Periódicos Biomédicos (Uniform Requirements for Manuscripts Submitted to Biomedical Journals: Writing and Editing for Biomedical Publication), acessíveis em http:// www.icmje.org ou http:// www.icmje.org/portuguese.pdf. Os critérios éticos da pesquisa devem ser respeitados. A pesquisa deve ter sido conduzida dentro dos padrões exigidos pelos órgãos de ética em pesquisa e aprovada pela comissão de ética da instituição onde a pesquisa foi realizada. Os conceitos e opiniões expressos nos artigos, bem como a exatidão e a procedência das citações, são de exclusiva responsabilidade do(s) autor(es).

Os artigos publicados são de propriedade da RBMFC, sendo vedada a reprodução, mesmo que parcialmente em outros periódicos, seja no formato impresso ou eletrônico, bem como a tradução para outro idioma sem a autorização do Editor. Todo o conteúdo RBMFC está sob a licença Creative Commons Atribuição-NãoComercial 3.0 Brasil (CC-BY-NY 3.0 BR) http://creativecommons.org/licenses/by$\mathrm{nc} / 3.0 / \mathrm{br} /$.

\section{Seções e Tipos de Trabalhos}

\author{
- Editorial \\ - Debate \\ - Perspectiva \\ - Artigos Originais \\ - Comunicações Breves \\ - Artigos de Revisão \\ - Casos Clínicos \\ - Atualização \\ - Diretrizes \\ - Ensaios \\ - Relatos de Experiência \\ - Documentos da SBMFC \\ - Cartas ao Editor \\ - Comentários \\ - Espaço Aberto \\ - Memória
}

O Editorial é de responsabilidade do editor da revista, podendo ser encomendado a terceiros. Os editoriais são limitados a 900 palavras e 10 referências.

A seção Debate é encomendada pelo editor. Trata-se de artigo teórico, que expresse a opinião qualificada de um especialista sobre um tema central da RBMFC, ou sobre um tema da atualidade, e que receberá críticas/comentários assinados de até outros três especialistas, também convidados pelo editor, apresentando uma réplica do autor principal. O artigo deve ter, no máximo, 2.000 palavras; 
os textos dos debatedores e a réplica, o máximo de 1.000 palavras cada um.

A seção Perspectiva trata de artigos teóricos, que expressem a opinião qualificada do(s) autor(es) sobre temas centrais da MFC ou da APS. Visam estimular a discussão e "oxigenar" controvérsias sobre aspectos relevantes da MFC e APS. O texto deve ser organizado em tópicos ou subitens, destacando-se na introdução o assunto e sua importância. As referências citadas devem dar sustentação aos principais aspectos abordados no artigo. O artigo deve ter, no máximo, 2.000 palavras.

A seção Artigos Originais é composta por artigos resultantes de pesquisa científica, apresentando dados originais de descobertas com relação a aspectos experimentais ou de observação, voltados para investigações qualitativas ou quantitativas em áreas de interesse da MFC e APS. Incluem estudos observacionais, estudos experimentais ou quaseexperimentais, avaliação de programas, análises de custoefetividade, análises de decisão e estudos sobre avaliação de desempenho de testes diagnósticos para triagem populacional. Cada artigo deve conter introdução com objetivos e hipóteses claras, desenho e métodos utilizados, resultados, discussão e conclusões. Deve apresentar, no máximo, 3.500 palavras, excluindo resumos, figuras e referências. As figuras, limitadas a cinco no conjunto, devem incluir apenas os dados imprescindíveis. As referências bibliográficas, limitadas a cerca de 25, devem incluir apenas aquelas estritamente pertinentes e relevantes à problemática abordada. A estrutura dos artigos originais de pesquisa é a convencional: Introdução, Métodos, Resultados e Discussão, embora outros formatos possam ser aceitos. A Introdução deve ser curta, definindo o problema estudado, sintetizando sua importância e destacando as lacunas do conhecimento que serão abordadas no artigo. As fontes de dados, a população estudada, amostragem, critérios de seleção, procedimentos analíticos, dentre outros, devem ser descritos de forma compreensiva e completa, mas sem prolixidade. A seção Resultados deve se limitar a descrever os resultados encontrados sem incluir interpretações/comparações. O texto deve complementar e não repetir o que está descrito nas figuras. A Discussão deve incluir a apreciação dos autores sobre as limitações do estudo, a comparação dos achados com a literatura, a interpretação dos autores sobre os resultados obtidos e sobre suas principais implicações e a eventual indicação de caminhos para novas pesquisas. Manuscritos baseados em pesquisa qualitativa podem ter outros formatos, admitindo-se Resultados e Discussão, em uma mesma seção, e Considerações Finais/Conclusões.

A seção Comunicações Breves inclui relatos curtos de achados de pesquisa que apresentem interesse para a MFC e APS, mas que não comportem uma análise mais abrangente e uma discussão de maior amplitude. Devem ter até 1.500 palavras (excluindo resumos, figuras e referências) e até 2 figuras e 10 referências. Sua apresentação deve acompanhar as mesmas normas exigidas para artigos originais.

A seção Artigos de Revisão inclui trabalhos que apresentam uma síntese atualizada do conhecimento disponível sobre temas da MFC e APS, buscando esclarecer, organizar, normalizar e simplificar as abordagens. Devem ter até 3.500 palavras, contendo introdução, desenvolvimento e conclusão. Subtipos:

1) Revisão sistemática e meta-análise, por meio da síntese de resultados de estudos originais, quantitativos ou qualitativos, objetiva responder à pergunta específica e de relevância para a MFC e APS. Descreve com pormenores o processo de busca dos estudos originais, os critérios utilizados para seleção daqueles que foram incluídos na revisão e os procedimentos empregados na síntese dos resultados obtidos pelos estudos revisados (que poderão ou não ser procedimentos de meta-análise);

2) Revisão narrativa/crítica: a revisão narrativa ou revisão crítica apresenta caráter descritivo-discursivo, dedicando-se à apresentação compreensiva e à discussão de temas de interesse científico no campo da MFC e APS. Deve apresentar formulação clara de um objeto científico de interesse, argumentação lógica, crítica teórico-metodológica dos trabalhos consultados e síntese conclusiva. Deve ser elaborada por pesquisadores com experiência no campo em questão ou por especialistas de reconhecido saber. Não há limite de referências.

A seção Casos Clínicos tem como objetivo abordar questões clínicas ou teóricas relevantes ou inovadoras para o diagnóstico ou para o manejo clínico de problemas ou condições de saúde importantes para a MFC e APS. Os artigos submetidos à publicação nessa seção deverão obedecer às normas gerais para todos os artigos da RBMFC, incluindo os aspectos éticos. Devem respeitar o limite de 2.000 palavras e 15 referências bibliográficas, além de serem estruturados em: Introdução, Descrição do Caso Clínico, Discussão e Referências. A introdução deverá apresentar o problema em questão, com uma breve revisão da literatura sobre os aspectos clínicos e terapêuticos, ou o diagnóstico diferencial em relação ao caso apresentado. O relato deverá ser sucinto, evitando-se dados redundantes ou irrelevantes para o esclarecimento do problema. A discussão deverá contrapor dados do caso apresentado (semelhanças e diferenças) com casos da literatura. Relatos de casos que explorem os componentes do Método Clínico Centrado na Pessoa ou que discutam o papel de filtro (prevenção quaternária) do Médico de Família e de outros profissionais da APS são bem-vindos.

A seção Atualização consiste em uma breve apresentação de um artigo de impacto na área da MFC e APS, recentemente publicado na literatura nacional ou internacional. Deve ser elaborado preferencialmente por um especialista na respectiva área do conhecimento e deve conter comentários sobre limitações metodológicas, implicações para a prática clínica ou para a pesquisa, em um texto de até 800 palavras e até 3 referências bibliográficas não incluídas na publicação em foco.

A seção Diretrizes é composta por artigos estruturados dentro das normas da Associação Médica Brasileira para diretrizes clínicas, validados pela SBMFC. Sua confecção, sob orientação da Diretoria Científica da SBMFC, é uma proposta de organizar e referendar o trabalho dos MFC no Brasil.

A seção Ensaios visa à divulgação de artigos com análise crítica e formulação de conhecimentos teóricos relevantes sobre um tema específico relacionado à MFC e APS. Deve ser apresentada em até 3.500 palavras, sem limites de referências. O texto deve ser organizado em tópicos para guiar os leitores quanto aos elementos essenciais do argumento desenvolvido.

A seção Relatos de Experiência é composta de artigos que relatem experiência inovadora em MFC e APS, acompanhada por reflexão teórica pertinente. Os textos devem ter até 3.500 palavras e 20 referências, com a seguinte estrutura: Introdução, Desenvolvimento e Conclusão.

A seção Documentos da SBMFC inclui documentos oficiais de colegiados oficiais ligados à SBMFC. Limite máximo de 2.500 palavras.

Em Cartas ao Editor, serão publicadas críticas a artigos publicados em números anteriores da revista ou nota curta, descrevendo criticamente situações emergentes no campo temático da RBMFC. Opiniões de leitores, apontamentos de erros editoriais e sugestões sobre a revista são bem vindas. As cartas devem ter, no máximo, 600 palavras e 5 referências.

A seção Comentários traz textos produzidos sob convite do editor, cujos autores comentam artigos recentemente publicados ou que serão publicados num futuro próximo. Os textos podem ter até 700 palavras e cinco referências. Observação: a seção para respostas, críticas ou comentários espontâneos aos artigos recentemente publicados é a "Cartas ao Editor".

A seção Espaço Aberto inclui textos de reflexão pessoal com maior liberdade formal, incluindo linguagens poética ou literária. Entrevistas com depoimentos de pessoas ou profissionais, cujas histórias de vida ou realizações sejam relevantes para a MFC ou APS, são publicadas também nessa seção. Os textos devem ter até 2.000 palavras.

A seção Memória, geralmente encomendada pelo editor, inclui textos sobre profissionais ou fatos históricos que tiveram destacada contribuição para a MFC e a APS no Brasil e no mundo. Máximo de 900 palavras e 05 referências, pode incluir uma fotografia. 


\section{Apresentação e Preparo dos Manuscritos}

Os textos deverão ser formatados em DOC. O padrão de formatação exigido é Word for Windows - versão 6.0 ou superior -, página padrão A4, letra Arial (tamanho 11), espaçamento entre linhas 1,5 e numeração sequencial em todas as páginas. As notas de rodapé devem ser limitadas o máximo possível, assim como as ilustrações (ver abaixo) - que devem estar incluídas no próprio texto principal.

Serão consideradas como ilustrações: 1) tabelas (elementos demonstrativos como números, medidas, percentagens, etc.); 2) quadros (elementos demonstrativos com informações textuais); 3) gráficos (demonstração esquemática de um fato e suas variações); 4) figuras (demonstração esquemática de informações por meio de mapas, diagramas, fluxogramas, como também por meio de desenhos ou fotografias). Vale lembrar que o miolo da revista é impresso em uma cor, o preto, e caso o material ilustrativo esteja em cor, será convertido para tons de cinza. O número de material ilustrativo deve ser de, no máximo, cinco por artigo, salvo exceções referentes a artigos de sistematização de áreas específicas do campo temático, quando deverá haver negociação prévia entre editor e autor(es). Todo o material ilustrativo deve ser numerado consecutivamente em algarismos arábicos, com suas respectivas legendas e fontes, e a cada um deve ser atribuído um breve título. Todas as ilustrações devem ser citadas no texto. As ilustrações devem ser confeccionadas em programas digitais que permitam boas condições para editoração e reprodução.

Os arquivos DOC não devem conter nome e instituição de nenhum dos autores do artigo. Durante o processo de submissão até a publicação do artigo, a identificação de autoria é informação restrita ao Editor da RBMFC, sendo incluída somente no campo de cadastro de metadados, durante a submissão eletrônica.

Os trabalhos que envolverem pesquisas com seres humanos deverão vir acompanhados da devida autorização do Comitê de Ética correspondente, na forma de "documento suplementar" (item 4 da submissão eletrônica).

Os trabalhos ("arquivos DOC") devem obedecer à seguinte sequência de apresentação:

1. Título em português e também em inglês e espanhol. Evitar títulos longos, utilizar no máximo 80 caracteres, incluindo espaços. Devem ser evitadas abreviaturas.

2. Resumo do trabalho em português e também em inglês (abstract) e espanhol (resumen), os quais devem ser estruturados no formato "Objetivo, Métodos, Resultados e Conclusões", com, no máximo, 350 palavras. Excetuam-se os ensaios teóricos ou equivalentes, cujos resumos são no formato narrativo, que, neste caso, terão limite de 150 palavras. Devem ser evitadas abreviaturas no resumo.

3. Palavras-chave em português e também em inglês (keywords) e espanhol (palabras clave): mínimo de 3 e máximo de 5 palavraschave ou descritores do conteúdo do trabalho, apresentados em português, inglês e espanhol de acordo com o DeCS - Descritores em Ciências da Saúde da BIREME - Centro Latino Americano e do Caribe de Informação em Ciências da Saúde (http://decs. bvs.br/). Observação: a versão final do título, do resumo e das palavras-chave para os idiomas inglês e espanhol ficarão sob responsabilidade da própria Revista.

4. Texto principal, de acordo com a estrutura recomendada para cada seção da RBMFC e tipo de trabalho. Observação: a designação completa à qual se refere uma abreviatura deve preceder a primeira ocorrência desta no texto, a menos que se trate de uma unidade de medida padrão.

4.1. Ilustrações (tabelas, quadros, gráficos e figuras) devem ser enviadas junto ao texto principal, conforme a ordem de aparecimento.
5. Referências: são de responsabilidade dos autores, deverão ser limitadas às citações do texto e numeradas segundo a sua ordem de aparecimento, de acordo com as regras propostas pelo Comitê Internacional de Revistas Médicas (International Committee of Medical Journal Editors): Requisitos Uniformes para Manuscritos apresentados a Periódicos Biomédicos (Uniform Requirements for Manuscripts Submitted to Biomedical Journals: Writing and Editing for Biomedical Publication), acessiveis em http://www.icmje.org ou http://www.icmje.org/portuguese.pdf. As URLs para as referências devem ser informadas quando possível.

\section{Exemplos:}

\section{Periódico}

Valla WV. Educação popular e saúde diante das formas de se lidar com a saúde. Revista APS. 2000; (5): 46-53.

\section{Livro}

Birman J. Pensamento freudiano. Rio de Janeiro: Jorge Zahar; 1994. $204 p$.

\section{Capítulo de livro}

Vasconcelos EM. Atividades coletivas dentro do Centro de Saúde. In: . Educação popular nos serviços de saúde. 3. ed. São Paulo: HUCITEC; 1997. p. 65-69.

\section{Dissertação}

Caldas CP. Memória dos velhos trabalhadores. [Dissertação]. Rio de Janeiro, Instituto de Medicina Social, Universidade do Estado do Rio de Janeiro; 1993.

\section{Evento}

Mauad NM, Campos EM. Avaliação da implantação das ações de assistência integral à saúde da mulher no PIES/UFJF; $6^{\circ}$ Congresso Brasileiro de Saúde Coletiva; 2000, Salvador. Salvador: Associação Brasileira de Pós-graduação em Saúde Coletiva; 2000. p.328.

\section{Documento eletrônico}

Programa de Pós-Graduação em Enfermagem. Anais do 3o Seminário Internacional de Filosofia e Saúde [CD-ROM]. Florianópolis: UFSC/ PEN; 2006.

Barbosa MA, Medeiros M, Prado MA, Bachion MM, Brasil V. Reflexões sobre o trabalho do enfermeiro em saúde coletiva. Rev. Eletr. Enferm. 2004; 06 (1): [online] [acesso em 2006 Out 01]. Disponível em: http:// www.fen.ufg.br/revista/revista6_1/f1_coletiva.html

Corona MBEF. O significado do "Ensino do Processo de Enfermagem" para o docente Improving palliative care for cancer [tese na Internet]. Ribeirão Preto: USP/EERP; 2005 [acesso 2007 Jun 28]. Disponível em: http://www.teses.usp.br/teses/disponiveis/22/22132/tde-06052005100508/

\section{Submissão Eletrônica}

A submissão de artigos para a RBMFC é feita apenas eletronicamente, e os textos deverão ser remetidos por meio da plataforma SEER, acessada em www.rbmfc.org.br. O cadastro no sistema e posterior acesso, por meio de login e senha, são obrigatórios para a submissão de trabalhos, bem como para acompanhar o processo editorial em curso. 
Durante o processo de submissão eletrônica, o autor responsável, além de enviar o "arquivo DOC" do artigo, deverá informar ainda:

- A Seção da RBMFC a que se destina o artigo;

- O idioma do artigo;

- Os nomes completos, endereços eletrônicos e as filiações de todos os autores; e

- Eventuais conflitos de interesses dos autores.

\section{Declaração de Autoria e responsabilidade dos autores}

No Passo 1 da submissão eletrônica de artigos, os autores deverão concordar com a responsabilidade de autoria, marcando a primeira caixa de seleção das Condições para Submissão.

As pessoas designadas como autores devem ter participado na elaboração dos artigos de modo que possam assumir publicamente a responsabilidade pelo seu conteúdo. A qualificação como autor deve pressupor: a) concepção e o delineamento ou a análise e interpretação dos dados; b) redação do artigo ou a sua revisão crítica; c) aprovação da versão a ser publicada.

Todo e qualquer trabalho a ser submetido, para que seja avaliado para publicação na RBMFC, obrigatoriamente deverá(ão) ser acompanhado(s) do(s) seguintes arquivo(s) complementares:

Declaração assinada por todos os autores de que: a) o trabalho não foi publicado e nem está sendo submetido para publicação em qualquer outro periódico; b) que todos os autores do trabalho concordam que o mesmo seja avaliado para publicação na RBMFC.

Formulário preenchido e assinado pelos autores referente ao possível "Conflito de interesses", que possa influir nos resultados.

Estes dois arquivos em formato pdf deverão ser postados no passo 4 do Processo de Submissão On-Line.

Após a aprovação do artigo, e antes da publicação final, todos os autores deverão especificar suas contribuições individuais na elaboração do artigo, enviando para o e-mail rbmfc@sbmfc.org.br uma "declaração de autoria e de responsabilidade", em formato pdf, com as assinaturas digitalizadas.

\section{Exemplo de Declaração de Autoria e Responsabilidade:}

"Declaro que participei de forma significativa na construção e formação deste estudo ou da análise e interpretação dos dados, como também na redação deste texto, tendo, enquanto autor, responsabilidade pública pelo conteúdo deste. Revi a versão final deste trabalho e aprovo para ser submetido à publicação. Declaro que nem o presente trabalho nem outro com conteúdo semelhante de minha autoria foi publicado ou submetido à apreciação do Conselho Editorial de outra publicação."

Observação: todos os autores de cada artigo receberão, após a publicação de seu trabalho, três exemplares da revista em que o seu estudo foi publicado.

\section{Ética em Pesquisa}

Os trabalhos que envolverem pesquisas com seres humanos deverão vir acompanhados da devida autorização do Comitê de Ética correspondente, na forma de "documento suplementar" (item 4 da submissão eletrônica).

\section{Agradecimentos}

Quando existirem agradecimentos a colaborador(es) que não se enquadra(m) na condição de autor(es), estes deverão compor um texto num arquivo DOC à parte, que deverá ser transferido na forma de "documento suplementar" (item 4 da submissão eletrônica). Os autores são responsáveis pela obtenção de autorização escrita das pessoas nomeadas nos agradecimentos.

\section{Dúvidas e Esclarecimentos adicionais:}

Sociedade Brasileira de Medicina de Família e Comunidade - SBMFC Rua Evaristo da Veiga, 16 sala 401

Centro - Rio de Janeiro - RJ

CEP: 20031-040

Fone: (21) 2524-8321

E-mail: rbmfc@sbmfc.org.br

Marcelo Marcos Piva Demarzo

Editor

demarzo@unifesp.br

Prof. Me. Armando Henrique Norman

Editor

editor.rbmfc@sbmfc.org.br

David Matos Milhomens

Bibliotecário - CRB-14/1268

Secretário Executivo da RBMFC

david@sbmfc.org.br 


\section{Purpose and Editorial Policy}

The Journal of Family and Community Medicine (RBMFC) is a quarterly scientific publication of the Brazilian Society of Family and Community Medicine (SBMFC), which has as its mission: to sensitize students, professionals and managers in the health area, on the themes of scientific interest of Family and Community Medicine (FCM) and Primary Health Care $(\mathrm{PHC})$, enabling exchanges between educational institutions, health services and social movement organizations, promoting the dissemination of multi and interdisciplinary approaches, serving as a vehicle for continuous education and ongoing health issues, with themes such as the FCM and the PHC.

The RBMFC aims at publishing original articles, perspectives, debates and discussions on all aspects of the FCM and the PHC, including clinical practice, training, organization of services, and public policies related to FCM and PHC.

\section{The peer review process}

Articles submitted to the Journal of Family and Community Medicine (RBMFC) will be reviewed by members of their Editorial and Scientific Boards, and also by ad hoc reviewers. The peer review process will preserve the identity of authors and their affiliations. The articles will be sent initially to the editor for screening and preliminary assessment, and subsequently distributed to reviewers, in accordance with the practice areas and their expertise, as well as the theme discussed in the article.

All texts are subjected to peer evaluation from two consultants from different institution from that of the author(s) - in a blind process in which the articles are discussed by the following aspects: the content suitability of the title; publication structure, clarity and relevance of the objectives, methodology, results and discussion; intelligible information, quotations and references to appropriate technical standards adopted by the journal, and relevance to the editorial of the publication. Consultants fill in the form of opinion, accepting, rejecting or recommending corrections and/ or necessary adjustments. Every opinion will include its rationale. This initial assessment process takes on average two months.

In case of request for changes to the article, it may be re-sent within 120 days, for a new evaluation from the consultants. The final result is then communicated to the author(s). If approved, the article is revised in spelling and grammar. The revised articles are sent for formal approval from the authors before being submitted for publication. Spelling and grammar review of abstracts and titles will be carried out in English and Spanish, by a specialist. No additions or modifications will be accepted after approval of the final review. The articles are then available for publication in order of protocol.

From 2011, RBMFC adopted the publishing of articles Ahead of Print, that is, the complete text of articles are published individually in the electronic edition, entitled Approved Articles, as soon as the editorial procedures are finalized. These articles will be published in future editions of the printed RBMFC.

The articles should be sent exclusively to RBMFC, not being allowed simultaneous submission to another journal. Contributions may be submitted in Portuguese, English or Spanish. Relevant topics in FCM and PHC, as well as the annals of the area, at the discretion of the Editor may be published as special supplements.

Articles submitted must conform to the RBMFC Editorial Policy and Guidelines below, which follow the Uniform Requirements for Manuscripts submitted to Biomedical Journals (Uniform Requirements for Manuscripts Submitted to Biomedical Journals: Writing and Editing for Biomedical Publication), available at http://www.icmje.org or http:// www.icmje.org/portuguese.pdf. The ethical standards of research should be respected. The research should have been conducted within the required standards from the agencies of research ethics approved by the ethics committee of the institution where the research was conducted. The concepts and opinions expressed in articles as well as the accuracy and validity of the citations are the sole responsibility of the author(s).

The papers published are property of RBMFC, being prohibited both reproductions, even partial consideration elsewhere, whether in print or electronic format, as well as translation into another language without the permission of the Editor. All RBMFC content is licensed under the Creative Commons CC-BY (Attribution Non-commercial Use).

\section{Sections and Types of Articles}

\author{
- Editorial \\ - Debates \\ - Perspective \\ - Original Articles \\ - Brief Communications \\ - Review Articles \\ - Clinical Cases \\ - Update \\ - Guidelines \\ - Essays \\ - Experiment Reports \\ - SBMFC Documents \\ - Letters to the Editor \\ - Commentary \\ - Open Section \\ - Memorial
}

The Editorial section is the editor's responsibility, which can also be set to a third party. The editorials are limited to 900 words and 10 references.

Debate section is ordered by the editor. It is a theoretical article that expresses the qualified opinion of a specialist on a RBMFC's central theme or a topical issue. The article receives critical comments signed up by three other specialists, also invited by the editor, and have an author's replica. The article should have, at most, 2,000 words; the texts of the debaters and the defense, at most 1,000 words each.

The Perspective section is about theoretical articles that express the qualified opinion of the authors on central themes of FCM or PHC. 
The articles aim to stimulate discussion and to "oxygenate" debates on relevant aspects of FCM and PHC. The text must be organized in topics or sub items and present the subject and its importance in the introduction. References should give support to key points raised in the article. The article must have, at most, 2,000 words.

The Original Articles section consists of articles resulting from scientific research, presenting original data regarding the findings of experience or observation, focused on qualitative or quantitative research in areas of FCM and PHC. Articles include observational and experimental or semiexperimental studies, program evaluation, costeffectiveness analysis, decision analysis and studies on performance evaluation of diagnostic tests for population screening. Each article should include an introduction with clear objectives and hypotheses, design and methods, results, discussion and conclusions, and have, at most, 3,500 words, not including abstract, figures and references. The figures, limited to 5 in the group should include only essential data. References, limited to about 25, should include only those that are strictly relevant and pertinent to the problem addressed. The structure of original research articles is conventional: Introduction, Methods, Results and Discussion, although other formats may be accepted. The Introduction should be brief, defining the problem studied, summarizing its importance and highlighting knowledge gaps that will be addressed in the article. The data sources, population studied, sampling, selection criteria and analytical procedures, among others, should be described in a comprehensive and complete way, but without prolixity. The Results section should be limited to describing the results without including interpretations or comparisons. The text should complement and not repeat what is described in the figures. Discussion should include authors' consideration of limitations of the study, comparison of the findings with the literature, the authors' interpretation of the results obtained and the main implications and possible indication for further researches. Manuscripts based on qualitative research may have other formats, Results and Discussion in one section, and Final Conclusions.

The Brief Communications section presents short reports of research findings concerning $\mathrm{FCM}$ and $\mathrm{PHC}$, not including a more comprehensive analysis and discussion of a greater magnitude. They should be up to 1,500 words (not including abstract, figures and references), and up to 2 figures and 10 references. Its presentation should follow the same standards required for original articles.

The Review Articles section includes texts that present an updated synthesis of available knowledge on topics of FCM and PHC, reaching to clarify, organize, standardize and simplify the approaches. They should be up to 3,500 words, containing introduction, development and conclusion. Subtypes:

1) Systematic review and meta-analysis, by synthesizing results of original studies, quantitative or qualitative, aims to answer the specific question of relevance to FCM and PHC. It describes in details the process of finding the original studies, the criteria used to select those that were included in the review and the procedures used in the synthesis of the results obtained by the studies reviewed (which may or may not be meta-analysis procedures)

2) Narrative/Critical Review: a narrative review or critical review presents a descriptive, discursive, dedicated to the comprehensive presentation and discussion of topics of scientific interest in areas of FCM and PHC. It should present a clear formulation of the scientific object of interest, logical argumentation, theoretical and methodological critique of the studies reviewed and conclusive synthesis. Reviews must be written by researchers with experience in that field or recognized expertise. There is no limit of references.

The Clinical Cases section aims to address issues relevant clinical issues or relevant or innovative theories for the diagnosis or clini-cal management of problems or health conditions relevant to FCM or PHC. Articles submitted for publication in this section should meet the general standards for all RBMFC articles, including ethical aspects.
They should respect the 2,000 words limit and 15 references, and be structured in: Introduction, Description of Clinical Case, Discussion and References. The introduction should present the matter with a brief review of the literature on clinical and therapeutic aspects, or the differential diagnosis in relation to the case presented. The report should be succinct, avoiding redundant or irrelevant data to solve the problem. Discussion should counter the data of the presented case (similarities and differences) with literature cases. Clinical Cases that explore the Person Centered Clinical Method components or discuss the role of GP's quaternary prevention and other professionals in the $\mathrm{PHC}$ are welcome.

The Update section consists of a brief presentation of an article of impact in the area of FCM and PHC, recently published in national or international literature. It should be prepared preferably by a specialist in their area of knowledge, and shall contain comments on methodological limitations, implications for clinical practice or research in a text of up to 800 words and up to 3 references not included in the publication focus.

The Guidelines section is composed of articles structured within the norms of the Brazilian Medical Association for clinical guidelines, validated by SBMFC. Its production, under the guidance of the Scientific Board of SBMFC, is a proposal to organize and endorse the work of the FCM in Brazil.

The Essays section aims to publicize articles with critical analysis and formulation of relevant theoretical knowledge about a specific topic related to FCM and $\mathrm{PHC}$, and must be presented in up to 3,500 words, with no limit for references. The text should be divided into topics to guide readers on the essential elements of the argument developed.

The Experience Reports section is composed of articles that report innovative experience in FCM and PHC, accompanied by relevant theoretical reflection. Texts should be up to 3,500 words and 20 references, with the following structure: introduction, development and conclusion.

The SBMFC Documents section includes official SBMFC documents from official collegiate associated with SBMFC. Maximum limit of 2,500 words.

In Letters to the Editor, it will be published criticisms of articles published in previous issues of the journal or a short note describing critical situations arising in the subject field of RBMFC. Opinions of readers, notes of editorial errors, and suggestions about the magazine are welcome. Letters must be no more than 600 words and five references.

The Commentary section includes texts produced at the invitation of the editor, where authors comment on articles recently published or to be published in the near future. Texts can be up to 700 words and five references. Note: the section for answers, criticisms, or spontaneous comments to the articles published recently is the " Letters to the Editor".

The Open Section section includes texts for personal reflection, with greater freedom of form, including literary or poetic language. Interviews with testimonials of people or professionals whose life stories or accomplishments relevant to the FCM or PHC, are also published in this section. Texts should be up to 2. 000 words.

The Memorial section, usually commissioned by the editor, includes articles on professionals or historical facts that were an outstanding contribution to the FCM and PHC, in Brazil, and worldwide. Maximum of 900 words and 5 references, and a photograph may be included.

\section{Presentation and Preparation of Manuscripts}

The texts should be formatted in DOC. The default formatting required is Word for Windows version 6.0 or higher standard A4 page, Arial font (size 11), 1.5 line spacing and sequential numbering on all pages. Footnotes should be limited as much as possible, as well as illustrations (see below) that should be included in the text page. 
Illustrations will be considered as: 1) tables (demonstrative elements as numbers, measurements, percentages, etc.); 2) frames (demonstrative elements with textual information); 3) charts (schematic demonstration of a fact and its variations); and 4) figures (schematic display of information through maps, diagrams, flowcharts, but also through drawings or photographs). Remember that the kernel of the magazine is printed in one color, black, and if the illustrations are in color, they will be converted to grayscale. The number of illustrations should be no more than five per article, except the items relating to specific areas of systematization of the subject field, when there should be prior negotiation between publisher and author(s). All illustrations should be numbered consecutively in Arabic numerals, with their captions and sources, and each must be assigned a brief title. All illustrations should be mentioned in the text. Illustrations should be made of digital programs that allow good conditions for editing and playback.

DOC files should not contain any name and affiliation of the authors. During the process of submission and publication of the article, the author's identification information belongs to the RBMFC Editor being included only in the metadata records field for electronic submission.

The texts that involve research with human subjects must be accompanied by the proper authorization from the relevant Ethics Committee in the form of "additional document" (item 04 of the electronic submission).

The texts ("DOC") shall have the following sequence of presentation:

1. Title in Portuguese, also English and Spanish. Long titles should be avoided, using at most 80 characters including spaces. Abbreviations should be avoided.

2. Summary of work in Portuguese and in English (abstract) and Spanish (resumen) should be structured in the format "Objective, Methods, Results and Conclusions ", with a maximum of 350 words. Exceptions are the theoretical essays or equivalent, whose abstracts are in the narrative format, which, in this case, will be limited to 150 words. Abbreviations should be avoided in the abstract.

3. Keywords in Portuguese and in English and Spanish (palabras clave): minimum 3 and maximum of 5 keywords or descriptors of the content of the work, presented in Portuguese, English and Spanish according to the DeCS - Health Sciences Descriptors of the BIREME- Latin American and Caribbean Center on Health Sciences (http://decs.bvs.br/). Note: the final version of the title, abstract and key words for English and Spanish will be responsibility of the journal.

4. Main text, according to the recommended structure for each section of the RBMFC and text type. Note: The full name of which refers to an abbreviation must precede the first occurrence in the text unless it is a standard unit of measurement.

4.1. Illustrations (tables, charts, graphs, and figures) must be sent together with the main text, according to the order of appearance.

5. References are the responsibility of the authors, should be limited to citations from the text, and numbered according to their order of appearance, according to the rules proposed by the International Committee of Medical Journal Editors: Uniform Requirements for
Manuscripts Submitted to Biomedical Journals: Writing and Editing for Biomedical Publication, available at http://www.icmje.org or http://www.icmje.org/portuguese.pdf. The URLs for the references should be informed when possible.

\section{Examples in http://www.nlm.nih.gov/bsd/uniform_ requirements.html and http://www.ncbi.nlm.nih.gov/ books/NBK7256/}

Periodic

Valla WV. Educação popular e saúde diante das formas de se lidar com a saúde. Revista APS. 2000; (5): 46-53.

\section{Book}

Birman J. Pensamento freudiano. Rio de Janeiro: Jorge Zahar; 1994. 204p.

\section{Chapter of the book}

Vasconcelos EM. Atividades coletivas dentro do Centro de Saúde. In: Educação popular nos serviços de saúde. 3. ed. São Paulo: HUCITEC; 1997. p. 65-69.

\section{Dissertation}

Caldas CP. Memória dos velhos trabalhadores. [Dissertação]. Rio de Janeiro, Instituto de Medicina Social, Universidade do Estado do Rio de Janeiro; 1993.

\section{Event}

Mauad NM, Campos EM. Avaliação da implantação das ações de assistência integral à saúde da mulher no PIES/UFJF; $6^{\circ}$ Congresso Brasileiro de Saúde Coletiva; 2000, Salvador. Salvador: Associação Brasileira de Pós-graduação em Saúde Coletiva; 2000. p.328.

\section{Electronic Document}

Programa de Pós-Graduação em Enfermagem. Anais do 3o Seminário Internacional de Filosofia e Saúde [CD-ROM]. Florianópolis: UFSC/ PEN; 2006.

Barbosa MA, Medeiros M, Prado MA, Bachion MM, Brasil V. Reflexões sobre o trabalho do enfermeiro em saúde coletiva. Rev. Eletr. Enferm. 2004; 06 (1): [online] [acesso em 2006 Out 01]. Disponível em: http:// www.fen.ufg.br/revista/revista6_1/f1_coletiva.html

Corona MBEF. O significado do "Ensino do Processo de Enfermagem" para o docente Improving palliative care for cancer [tese na Internet]. Ribeirão Preto: USP/EERP; 2005 [acesso 2007 Jun 28]. Disponível em: http://www.teses.usp.br/teses/disponiveis/22/22132/tde-06052005100508/

\section{Electronic Submissions}

The submission of papers for only RBMFC is done electronically, and the texts should be sent through the SEER platform, available from www. rbmfc.org.br. The Registration and subsequent access through the login and password are required for submission of texts as well as to monitor the ongoing editorial process. 
During the electronic submission, the author, besides sending the "DOC file" of the article must also inform:

- Section of RBMFC the intended article;

- The language of the article;

- The full names, addresses and affiliations of all authors, and

- Potential conflicts of interest of the authors.

\section{Statement of authorship}

In the 1st step for electronic submission of articles, the authors must agree with the authorship responsibility, marking the first box from the options from the Conditions for Submission.

The people designated as authors should have participated in drafting the articles so that they can take public responsibility for their content. Authorship should be based on: a) conception and design or analysis and interpretation of data, b) drafting the article or revising it critically, and c) approval of the version to be published.

After approval of the article, and prior to final publication, all authors should specify their individual contributions in drafting the article, send to the postal address of the RBMFC the "declaration of authorship and responsibility", signed by each author.

\section{Sample Statement of Authorship and Responsibility:}

"I declare that I participated significantly in the construction and production of this study or analysis and the data interpretation, as well as the writing of this text, taking, as an author, public responsibility for its content. I reviewed the final version of this work and approve it for submission for publication.

I declare that neither this nor any other article with similar content done by me was published or submitted to the editorial board of another publication".

Note: all the authors of each article will receive, after the publication of their work, three copies of the journal in which their study was published.

\section{Research ethics}

The researches with human beings should accompany an accurate authorization from the corresponding Ethics Committee, labeled "additional document" (4th item for electronic submission)

\section{Acknowledgments}

When there are acknowledgements to collaborators that do not take part in the condition of author, these should compose another text in a DOC file format, which should be transferred and labeled "additional document" (4th item for electronic submission). The authors are responsible for obtaining the written authorization of the people mentioned in the acknowledgements.

\section{Additional doubts and clarification:}

Sociedade Brasileira de Medicina de Família e Comunidade - SBMFC Brazilian Society of Family and Community Medicine - SBMFC Rodovia Rua Evaristo da Veiga, 16 sala 401

Centro - Rio de Janeiro - RJ

CEP: 20031-040

Fone: (21) 2524-8321

E-mail: rbmfc@sbmfc.org.br

Marcelo Marcos Piva Demarzo

Editor

demarzo@unifesp.br

Prof. Me. Armando Henrique Norman

Editor

editor.rbmfc@sbmfc.org.br

David Matos Milhomens

Librarian - CRB-14/1268

Executive Secretary RBMFC

david@sbmfc.org.br 


\section{O MELHOR CONTEÚDO DE ATUALIZAÇÃO EM MEDICINA DE FAMÍLIA E COMUNIDADE SEMPRE PRÓXIMO A VOCÊ.}

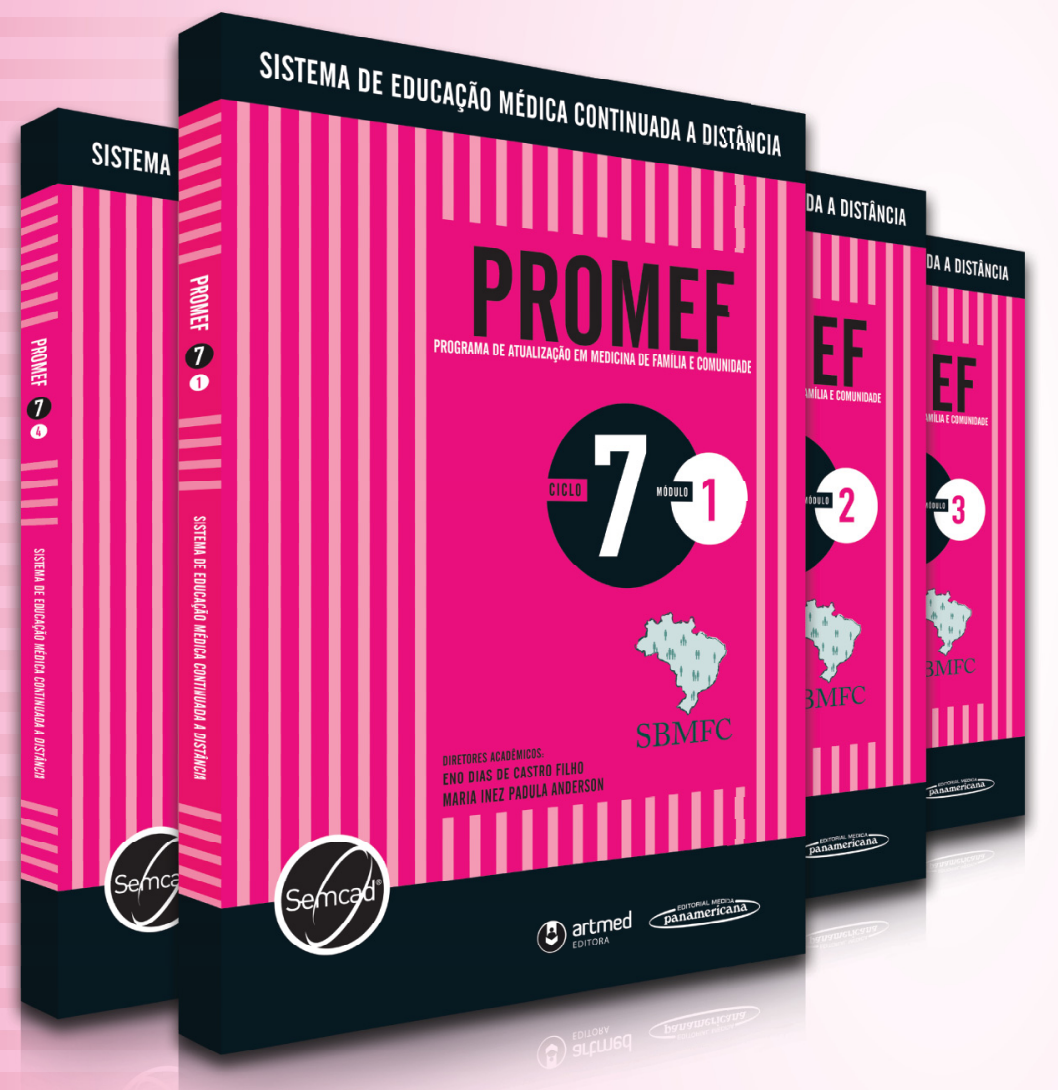

\section{INSCREVA-SE JÁ.}

www.semcad.com.br infolasemcad.com.br

5130252550

Programa de Atualização em Medicina de Família e Comunidade

\section{Saiba mais sobre o PROMEF:}

Há 7 anos o PROMEF é uma excelente alternativa para atualização profissional em medicina de família e comunidade. 0 programa é chancelado pela SBMFC e conta pontos para sua atualização profissional. Além disso, o sistema de ensino a distância facilita a sua vida, pois se adapta ao seu tempo e sua disponibilidade. 